DOERMOTC - 020121

\title{
Soil Remediation Test
}

Final Report for the Period October 18, 1999 - July 31, 2000

Date Published: April 1, 2002

D. M. Manlapig

W. Williams

\section{PREPARED FOR THE UNITED STATES DEPARTMENT OF ENERGY FOSSIL ENERGY/ROCKY MOUNTAIN OILFIELD TESTING CENTER}

Work Perfintmed Lnder Rocky Mountain Oiffeld Testing Center (RMOTC) CRADA No. 20V0-1002

Distributiun A - Apprnvert lor public release; further dissemination unlimited (Unclassified Unlimited)

Approved by:

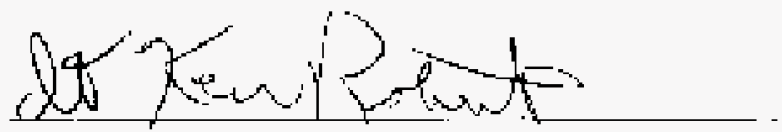

RMOTC Manager

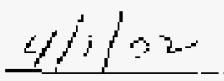

Date 


\section{Disclgitmer}

This repurl wats preparcel as an account of work sponsored by an ingency of the Unitod States Government. Neither the: United States Gowemment nor any atgency therool, nor

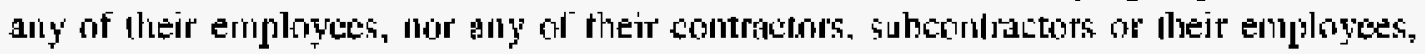
makes any wananty, cxpress or implicd, or assumes any legal liability or responsibility for the accuracy, completeness, or any third party's use ar the results of such use of any information, apparants, ponduer, or proess diselosed, or tepresents that its use would hot intringe pliwately owned rights. Reference herein to any specific coromercial product, pancess, or service by trade name, trademark, Janufacturer, ar otherwise, does not mecosarily constitute ot imply its endorsement, recommendation. or favoring by the Lnica states Govemmonl or any agency thereof or its contractors or subcontrators. The views and opinions of authors expressed herein do not necessurily state or reflect those of the United States Govemment or any agency thereof. 


\begin{abstract}

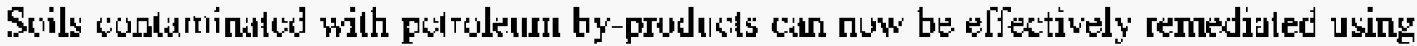
a variety of tectonologies. Among these ane in-situ biotemediation, land farming, and landrildreplacing of sonl. The lange we efteciencies and cost thectiveness al these uxhologios has boen voll documented. Exsorbet l'us is showing prumise as an in-situ bionemediation agent. It is made of 1]aturally grown Spaglınum Peat Moss which has been

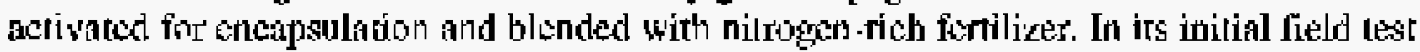
in Caracas, Venezaela, jt was able to remedjate crude oil-contaminated soil in 90 days at less rlan ha]f of the cost. of compreting lechnologies.

Waste Solutions, Corp, and the US Department of Energy signed a Cooperative Research ugd Developonent Agreement 10 test Fxsnothet. Plus at the Rocky Mauntain Dilfield Testing Center rear Casper. Wyoming. As part of the test sojl contaminaled with orude oil was troaled with Exsorbut ylus to aid the in-silu bioremediation prosess. Quantitative total petroleum bydrocerbon (TPH) measunements wese acquired ocmparimg the pertormance of Fxsotbet Flus with an adjocent plot undergong natural unadded in-situ bioresuedialion.
\end{abstract}




\section{Introduction}

The Rocky Mountatn Oilteld Testing Centes (RMOTC) is located at the US Department of Fnergy's (TOE) Naval Pollollour Rustre No. 3 (NPR 3) aproximately 35 miles montheast of Casper, Wyoming. RMOTC was selatelisted, by the DOF. 10 pather with the petroleum industry to improwe domestic produclion through the field testing of new production, drilling, and onvironmental tchonologiss, and disseminaring information ton

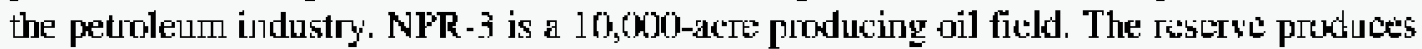
from 500 wells ranging in depth from $250 \mathrm{ft}$. to $6000 \mathrm{ft}$... and all are avalable fior tield tassl.

Durifig Fiscal Yoar (FY) 2000, tatk battery B-1-20 was taken out of serrice and docommissionce. Hydrocarbon conlaminatod soils were galhered and placed in a land lann anea permited by Wyuning Oil and Gas Conburation Commissiun WOGCCy. The site measures aptyoximately $200^{\circ} \times 300^{\circ}$. It comains 30,040 cubic feet of contaminatco soil. RMOIC selected this tite to condect a fich lest using a connercial peat moss

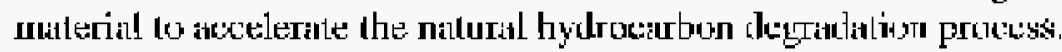

\section{Test Destription}

RMOTC partnend with a private indusiry compary to tent a commenial peat moss materiat to add the in-situ bionmoliation procss Quantiative tolal pelrolen bydnocatbon (TPH) neasurements were acquircd comparing the performance of the soil amendment with an adjatent plot undergoing natural unaided in-situ bioreInediation.

The ohjective of this tesl was to promote a beter and more cob-cellective Intethed of eleaning up crude oil spills and improving the environment.

Several measunes of hydrocarton are aveilitble. EPA measunes hydrocarbons by a standardjed analytical protocol called EPA-41s.1. known as oteG. This test. when

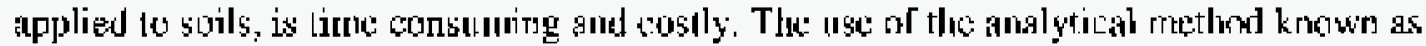
EPA-418. I was used to conply with Wyoming oil and Gas Conserration Commission. ivles. Two valiations of TPH are avalable: TPH-Iufrared and TPH-Gas Chomatography with Flame Iomization Teteston. Neichor DRG nor TPH sqrve as an irdequate index for Iracking bionemediation teatment performance. Both inthody demonstrate little ur no decrease ij hydrocarbon content as the result of bioremediation because the method repors biomass as TPH. The resulrs demonstratcd no roduction of TPH as the result of Ireatungent

Gas shromatographic analysis of total petroleum hydrostron standardized to peak: area

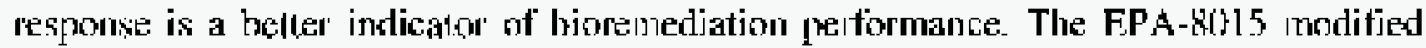
method, which is gas chrumatographic and mcasures dicse and gagoline range organic compounds, was used in coljunction with EPA-4 I 8. I moditied method to detemine the binretrodiation perfarmangs of the lend farm. 


\section{Experimental Design and Procedure}

\section{Testing Procedures}

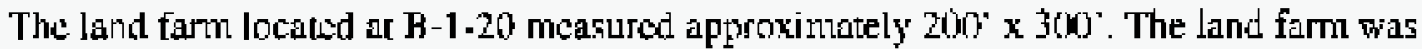
diwided into two separate plotir. a control and a treated both Insasuring $100^{\prime} x$ 100'. A small uractor was used to disk the goil 6 inches deep. This technique distributes the soil amendments and aerated the system. Each month the land farm was disked to allow a

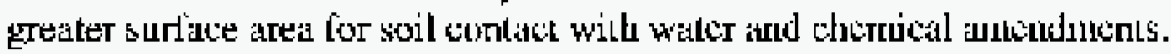

A composite sample from fine distinct sections tion the conthol and tive from the treated plot wore wolledud using a stowel to dig a ure-ront doep profilc. At eash of the five sections a soil scoop was used to meagure four scoops per scction. The mpresentive samples fin' the control and for the treated plots were unixed in a five-gallon bucket soparalsy to obcain a composite for cact scetion. The soil sifter was used to homogenize the segliments. From these serdiments three soil samples from the troated and thres sail samples ftom control thostimg plors are stored in six $250 \mathrm{ml}$ sasple jas: Four at the samples were taken to Encrey Labs for analysis using the slandard mothonds FPA-418.1 moditied and fiPA-8015 modified. The two remilining soil samplex were analyzed using the Hach NPK-1 soil tegt kit to mensure nitrogen, phosphorus, potassium, and $\mathrm{pH}$ in soil. To prowcn cross conamination from cach plot be showel, sifter soil scoop, and fiveyallor buckel were sleated wilh flistilled waler.

\section{Discussion}

Orgaric annendments in the form of pat moss or low salt manure improve suil struclure.

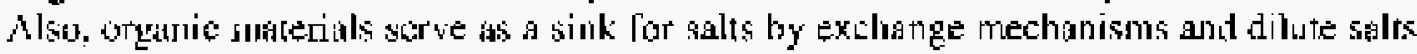
in soil solulion by increasinge moisure-holding capacicy. Fertilicy adjustmonts in the form of fertilizer amendments, aemion, and moisture are necessary for bioromediation ptogtan. Fentilizet amendments include nitrogen, phosphorus, and potassium. Ammonium ritrate, ammonimi sulfats and urea are gond gitrogen souress. Split application coupled with tillage sperations inencase fertilizer use effieiency, and lessen the potential for euttophte stagration. Research show the optinum cuton. nitrogen (C:N) ratio for lield degradation of pelroleuro hydrocarbon is $150: 1$. A lower C.N ratio theoretically will improve degradation rates. Phosphorus and polissium ire elérlents that may be limiting in the snil matrix and cause a positive response when added to the system A nitrocin, phosphors, and folassium (N:P:K) tatio of 4:1:1 provides good balanes of these elements. They shopld be applied in split application to increase ufficiency. Fentilizer applications should be lilled into the soil to distribute the amendment through the reatment cone. Tilling also induses oxygen into the swil. Gencrally sornt other variable, such as water use efticiency or free air exchange linits the ubility or addicier mots: mulnituls. 
Analysis from the Huth soil kil shews that the soil on both the trealed and conlrol plots range from a fll of 6 to 7 indicating the soil is fajty neutral in hydrogen jons. High lewels of phosphurus and low levels of diongen were also indjated by the Hach soil test kit. These results indicate that the $\mathcal{N}: \mathcal{R}: K$ ration is not belanced.

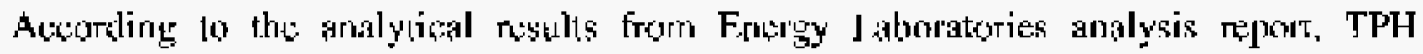
measured by El'A 418.1 and EPA 801 in modifict from dates $5 / 25 / 00$ os $7 / 13 / 00$ has decreased on the treated plot. TPH dweteased by $2.170 \mathrm{mg} / \mathrm{Kg}$ according to the EPA 418.1 togt results (Figurc 1) Analytical roiules frotn kaboratory analysis indieate that diesel cange organics (EPA gols moditied) decreased in concentration by a factor of

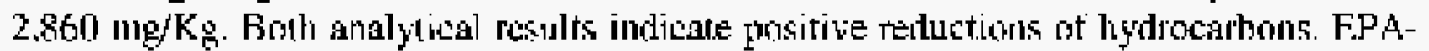
418.1 msasures tolal hydrocaton biomass. while FPA-8015 modifich megruns spocific DRO compounds. However. variation in TPH and diesel range ortgrics has been observed from the analytical test analysis. This con be caused by in number of varables stch as: soil moisture content, soil sampling techniques, disking procedures terilizer

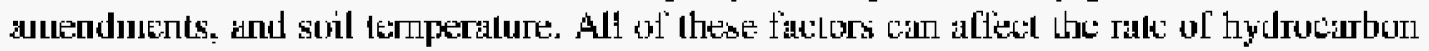
degradation and also influence anolytical test t'soults.

\section{Conclusion}

Remediation enails biodegrailation of coule oil using native soils' microtlon.

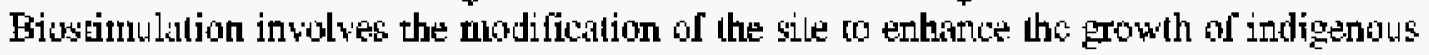
microbes already present. Pardmeters having a profound effect on rates of hydrucarbon degradation include: initial oil level. moisture content, aeration, Carbon:Nitrogen ratio, and other fertilizer amendments. Through observation and mearch the binemediation of the comtaminated sile indicales a reduclion af hydrociobon lewels. For optimal remediation of the site, the following recorsmentations could hare heen endared:

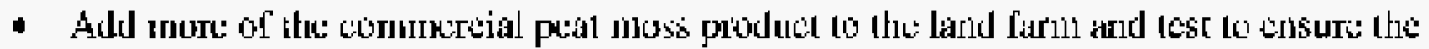
proper balance of the N:P.K ratio.

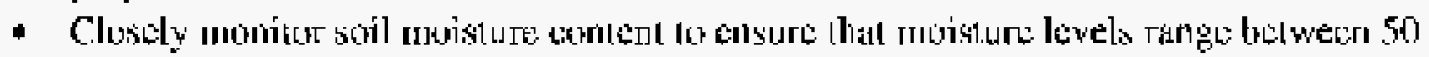
and 80 porecti of the soil water-holding capicily.

- Disk the site twice a month to a depth of 10 inches to ensure ateration of the system. and to distribute the soil atmetidments.

- Chinge to cross section sampling technigue to ensure a good representative composite of the entire plot.

Due to lack of copponse trom the clicnt nonc of the recommendations wor enactod and the project ended prematurely- 


\section{Appendix A-References}

Dend Lloyed and Halliday, Soll Reinediation For The Paralcum Fxtraction Industy, Pen łell Publishing. Fulsi, OK, 1994

Kogpeci Paul Calabreste Bonazountas, Fat. Contaminated Soils, Amherst Scientific

Éublishers, Atrherst. MA, 1999

Oppenheimer Biotechnology, Inc. lntp:/Hww obiacomu 


\section{Appendix B-Figure}

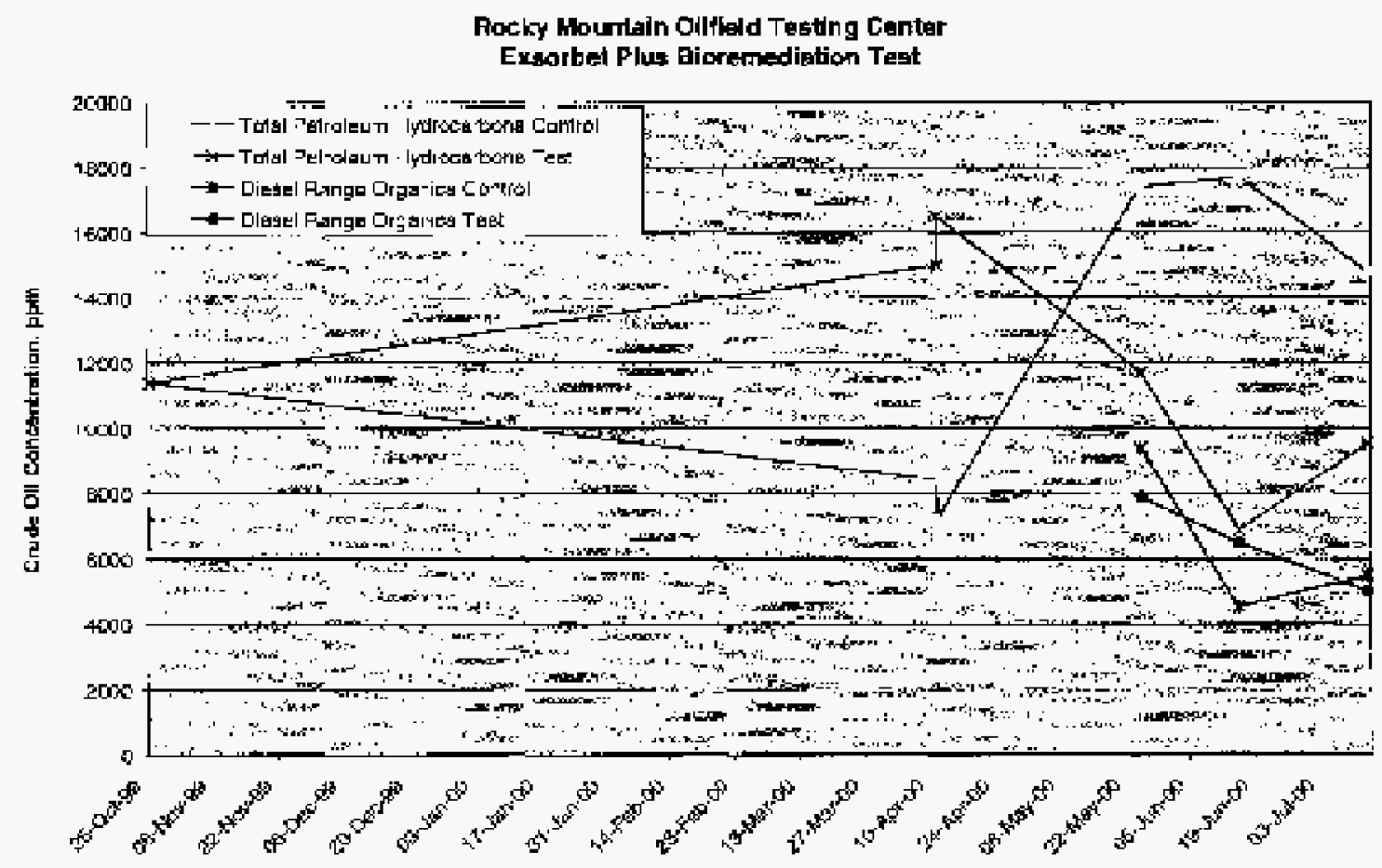

Frgare-1 